
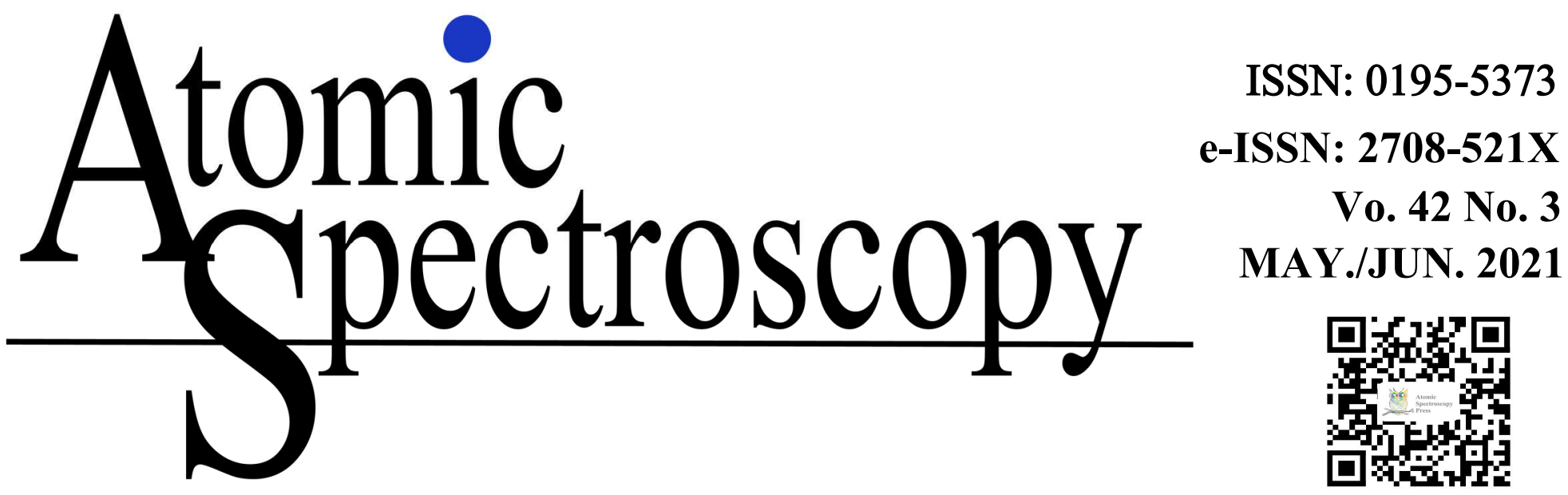

www.at-spectrosc.com

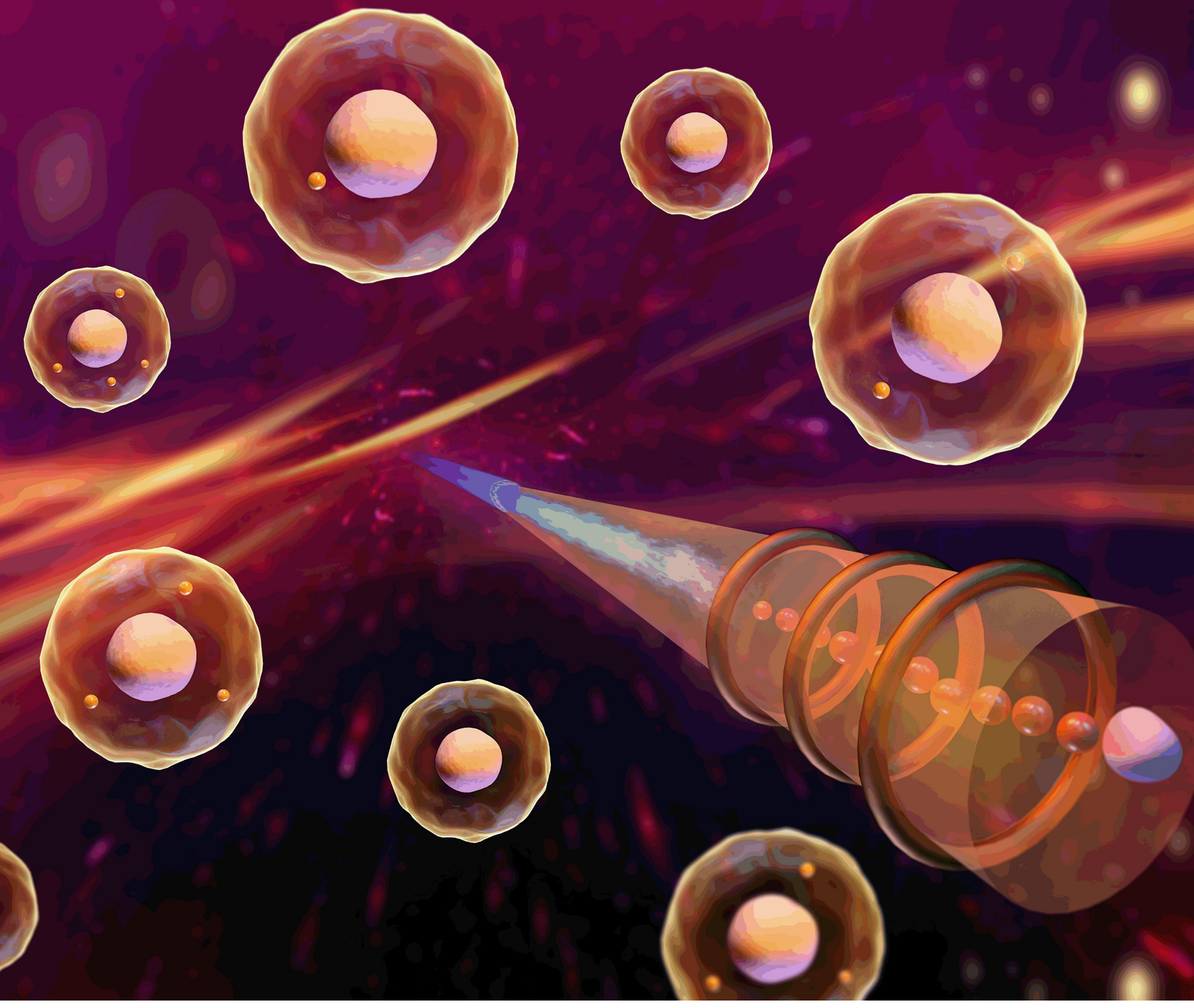

Cover Feature:

Quantitative Analysis of Gold Nanoparticles in Single Cells with Time-resolved ICP-MS Jinhui Liu, Lingna Zheng, Junwen Shi, Xing Wei, Xue Li, Mingli Chen, Meng Wang, Jianhua Wang, and Weiyue Feng

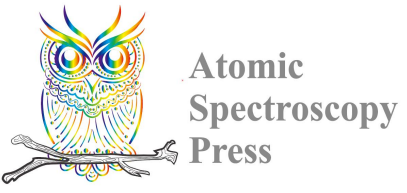


Alonitersocy

\title{
Quantitative Analysis of Gold Nanoparticles in Single Cells with Time-resolved ICP-MS
}

\author{
Jinhui Liu, ${ }^{\text {a,b }}$ Lingna Zheng, ${ }^{a}$ Junwen Shi, ${ }^{\mathrm{c}}$ Xing Wei, ${ }^{\mathrm{b}}$ Xue Li, ${ }^{\text {a }}$ Mingli Chen, ${ }^{\text {b,* }}$ Meng Wang, \\ Jianhua Wang, ${ }^{\mathrm{b}}$ and Weiyue Feng a \\ ${ }^{a}$ CAS Key Laboratory for Biomedical Effects of Nanomaterials and Nanosafety, CAS-HKU Joint Laboratory of Metallomics on Health and Environment, \\ and Beijing Metallomics Facility, Institute of High Energy Physics, Chinese Academy of Sciences, Beijing 100049, P.R. China \\ ${ }^{b}$ Research Center for Analytical Sciences, Department of Chemistry, College of Sciences, Northeastern University, Shenyang 110819, P.R. China \\ ${ }^{c}$ Institute of Nanochemistry and Nanobiology, Shanghai University, Shanghai 200444, P.R. China
}

Received: February 8, 2021; Revised: February 27, 2021; Accepted: February 28, 2021; Available online: March 4, 2021.

DOI: $10.46770 / A S .2021 .102$

ABSTRACT: Single-cell inductively coupled plasma mass spectrometry (SC-ICP-MS) has been introduced for the analysis of intracellular essential elements and nanoparticles (NPs) at the single cell level. However, it is still quite challenging for accurate and reliable determination. In this work, a high-efficiency sample introduction system was used for single cell analysis with ICP-MS. The system includes a microconcentric nebulizer, a low-volume single pass spray chamber, and a syringe pump. The transport efficiency of single cells was greatly improved to $\sim 12 \%$. In addition, ${ }^{197} \mathrm{Au}$ signals in individual HepG2 cells, after incubation with gold nanoparticles (AuNPs) at the concentrations of $0.1,0.5$, and $1 \mu \mathrm{M}$ for $12 \mathrm{~h}$, were analyzed by time-resolved ICP-MS with dwell times of $100 \mu$ s and $5 \mathrm{~ms}$, respectively. The ${ }^{197} \mathrm{Au}$ signal-to-background ratio $(\mathrm{S} / \mathrm{B})$ at $100 \mu \mathrm{s}$ dwell time was much higher than at $5 \mathrm{~ms}$. For quantitative analysis, AuNP standard reference materials were used for calibration. The SC-ICP-MS data using NP calibration were in good agreement with those using solution ICP-MS analysis, validating the developed SC-ICP-MS method.

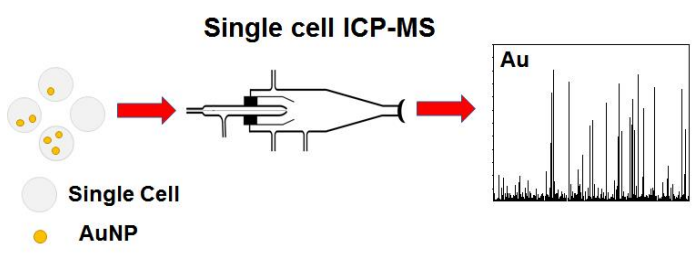

\section{INTRODUCTION}

Cells are the basic structural and functional units of living organisms. Traditional biomedical research is mainly based on cell population, which masks the differences between individual cells. Rapid advances in analytical techniques enable scientists to conduct biomedical research at a single cell level. ${ }^{1,2}$ Single cell analysis cannot only obtain the heterogeneity and diversity of the individual cell, but also offers profound insight into the various biological processes of the living organisms, which has become of great interest to the scientific community.

Nanoparticles (NPs) show unique characteristics and are significantly different from their large-size counterparts. ${ }^{3,4}$ After exposure to the living organism, NPs will be internalized into the cells, which is similar in process to the large macromolecular substances and viruses. ${ }^{5}$ NPs can promote cellular proliferation or differentiation ${ }^{6,7}$ and induce cytotoxicity, oxidative stress, and even apoptosis. ${ }^{8,9}$ For estimating cellular uptake of NPs, conventional methods are based on the analysis of the cell populations, which can only provide average information of the large numbers of cells and ignore the differences of individual cells. ${ }^{10}$ However, single cells behave differently after environmental stimuli, such as exposure to NPs, even the cells with the same genotype may show great heterogeneity. ${ }^{11,12}$ Therefore, the study of the uptake of NPs by single cells is crucial, and reliable methods for single cell analysis are urgently needed.

Several analytical techniques have been established for the analysis of elements in biological samples: for example, atomic absorption spectrometry (AAS), ${ }^{13}$ atomic fluorescence spectrometry (AFS), ${ }^{14}$ and inductively coupled plasma optical emission spectroscopy (ICP-OES). ${ }^{15}$ The above methods, however, are still difficult for the analysis of NPs in single cells mainly due to their high detection limits. Inductively coupled 
plasma mass spectrometry (ICP-MS), using a time-resolved mode, has already been developed for the analysis of intracellular elements, named single cell (SC)-ICP-MS. ${ }^{16,17} \mathrm{Li}$ et al. studied the signals of ${ }^{238} \mathrm{U}$ in single Bacillus subtilis cells by time-resolved ICP-MS and found that the individual cells behave in an ICP more like solid particles rather than wet droplets. ${ }^{18}$ Ho et al. determined the $\mathrm{Mg}$ content in individual algae cells by time-resolved ICPMS. ${ }^{19}$ Zheng et al. determined quantum dots, $\mathrm{Gd} @ \mathrm{C}_{82}(\mathrm{OH})_{22}$, and cisplatin with time-resolved ICP-MS and studied their uptake behavior at a single cell level. ${ }^{20,21}$

Traditional sample introduction systems are not suitable for SCICP-MS because of the low detection efficiency of single cells (typically $<1 \%$ ). Many advances in instrument development have been made to increase the efficiency. Single cell pre-treatment devices of the microdroplet generation were coupled with timeresolved ICP-MS for the measurement of cellular uptake of $\mathrm{NPs},{ }^{22,23}$ which improved throughput and precision of SC-ICPMS analysis. Wei et al. developed high-throughput droplet-free single cell sampling devices based on inertial force in spiral pipes, which removed the oil phase and therefore avoided carbon deposition. ${ }^{24,25}$ More efforts need to be made to further improve the transport efficiency of single cells.

Data acquisition modes have a significant effect on the results of SC-ICP-MS. The duration of transient signals from a single particle / cell was reported to be $\sim 0.5 \mathrm{~ms}$ in plasma. ${ }^{26,27} \mathrm{In}$ single cell analysis, most quadrupole ICP-MS analyses suffer from a settling time, which may miss single cell events, and cause cycle loss. In addition, many commercial quadrupole ICP-MS instruments can only operate with dwell times at the millisecond range, and thus the dwell times are reported as being longer than the duration of a single cell, reported as $1 \mathrm{~ms},{ }^{24} 4 \mathrm{~ms},{ }^{28,29} 5 \mathrm{~ms},{ }^{20-}$ 22 and $10 \mathrm{~ms}^{23,30}$ Under these circumstances, the number of NPs introduced into the ICP-MS should be properly controlled to avoid overlapping signals from more than one NP. In addition, the signal-to-background ratios ( $\mathrm{S} / \mathrm{B})$ deteriorate by using long dwell times. Data processing methods, such as iterative algorithms as proposed by Pace et al. ${ }^{31}$ are needed to distinguish cellular events from background noises, which is quite challenging, especially for the weak signals of single cells.

In this work, the uptake of AuNPs by individual HepG2 cells was determined by SC-ICP-MS. A high-efficiency sample introduction system was employed to improve the transport efficiency of the single cells. A new generation of quadrupole ICPMS with zero settling time and $100 \mu$ s dwell time was used to increase the signal-to-background ratio (S/B). For quantitative analysis, AuNP standard materials were used as the calibration standards. The quantitative results were compared with the results by cell digestion and solution analysis with ICP-MS.

\section{EXPERIMENTAL}

Chemicals. Ultrapure water (18.2 $\mathrm{M} \Omega \mathrm{cm}$, Milli-Q water purification system, Millipore Corporation, USA) was used throughout this work. The AuNP certified reference material GBW(E)120127 (diameter: $43.7 \pm 1.5 \mathrm{~nm}$ ) was purchased from the National Central Nanoscience and Technology (Beijing, P.R. China). Dulbecco's Modified Eagle Medium (DMEM) high glucose was purchased from Thermo Scientific (USA). Fetal bovine serum (FBS) and Penicillin Streptomycin were purchased from Gibco BRL Co. Ltd. (USA). Trypsin-EDTA solution was bought from the Beyotime Institute of Biotechnology (Beijing, P.R. China). ICP-MS multi-element standards, containing $10 \mathrm{mg} \mathrm{L}^{-1}$ $\mathrm{Be}, \mathrm{Ce}, \mathrm{Fe}, \mathrm{In}, \mathrm{Li}, \mathrm{Mg}, \mathrm{Pb}, \mathrm{U}$, were purchased from PerkinElmer, Inc. (USA). Nitric acid (MOS grade) was bought from Beijing Chemical Reagent Company (Beijing, P.R. China). The gold standard solution was bought from the National Institute of Metrology (Beijing, P.R. China).

Cell culture and treatments. A human liver cancer cell line (HepG2) was used in this work. The HepG2 cells were cultured at $37^{\circ} \mathrm{C}$ in $5 \% \mathrm{CO}_{2}$ in high glucose $\left(2 \mathrm{~g} \mathrm{~L}^{-1}\right)$ DMEM medium, which contained $10 \%$ FBS, $100 \mu \mathrm{g} \mathrm{mL}^{-1}$ streptomycin, and $100 \mathrm{IU} \mathrm{mL}^{-1}$ penicillin. After the AuNPs solution was sonicated, the HepG2 cells were incubated for $12 \mathrm{~h}$ with AuNPs at 0.1, 0.5, and $1 \mu \mathrm{mol}$ $\mathrm{L}^{-1}$. The cells were collected after trypsin digestion, centrifugation, and thorough washing with $0.9 \% \mathrm{NaCl}$ solution. For single cell analysis, one part of the collected cells was immobilized with $70 \%$ (v/v) pre-cooling ethanol at $4{ }^{\circ} \mathrm{C}$ for $12 \mathrm{~h}$, centrifuged, counted, and resuspended in ultrapure water with a cell density of $10^{5} \mathrm{~mL}^{-1}$. The cells' morphology was examined with a bright field microscope (EVOSFL Auto, Life Technologies Corporation, USA). The remaining cells were counted with a hemocytometer, digested with nitric acid in closed vessels at $150{ }^{\circ} \mathrm{C}$ for $12 \mathrm{~h}$, and analyzed with solution nebulization ICP-MS.

Time-resolved ICP-MS measurement. A quadrupole ICP-MS (NexION 300D, PerkinElmer, Inc., USA) was used in this work. The sample introduction system for SC-ICP-MS was composed of a HEN microconcentric nebulizer (Meinhard, USA), a lowvolume, single pass spray chamber (Viktor Beijing Technology Co. LTD, P.R. China), and a SP120PZ syringe pump (World Precision Instruments, UK). The typical instrumental parameters are shown in Table 1. The single cell suspension was measured in a timeresolved mode at the dwell time of $100 \mu \mathrm{s}$ or $5 \mathrm{~ms}$. The transport efficiency of the system was calculated by the ratios of single-cell events determined by ICP-MS to single cells in suspensions introduced into the ICP-MS, which had been counted in advance with a hemocytometer. The data collection was carried out through the Syngistix Single Cell Application Module. All data were processed using Origin 8 software (OriginLab Corporation, USA) and Excel 2018 software (Microsoft, USA). 
Table 1. Typical Parameters for SC-ICP-MS

\begin{tabular}{|c|c|}
\hline ICP-MS & PerkinEImer, NexION 300D \\
\hline Nebulizer & $\begin{array}{l}\text { Microconcentric nebulizer } \\
\text { (Meinhard HEN) }\end{array}$ \\
\hline Spray Chamber & $\begin{array}{l}\text { Low-volume, single pass spray } \\
\text { chamber (Viktor Beijing) }\end{array}$ \\
\hline Carrier gas & Argon \\
\hline Nebulizer gas flow $\left(\mathbf{L}\right.$ min $\left.^{-1}\right)$ & 0.62 \\
\hline Makeup gas flow $\left(\mathrm{L} \mathrm{min}^{-1}\right)$ & 0.55 (Total flow) \\
\hline Auxiliary gas flow (L min $\left.{ }^{-1}\right)$ & 1.2 \\
\hline Plasma gas flow $\left(\mathrm{L} \mathrm{min}^{-1}\right)$ & 18 \\
\hline RF Power (W) & 1600 \\
\hline Sample flow rate $\left(\mu \mathrm{L}\right.$ min $\left.^{-1}\right)$ & 40 \\
\hline Dwell time & $100 \mu \mathrm{s}, 5 \mathrm{~ms}$ \\
\hline Data acquisition (s) & 100 \\
\hline Isotope determined & ${ }^{197} \mathrm{Au}$ \\
\hline
\end{tabular}

\section{RESULTS AND DISCUSSION}

Preparing single cell suspensions. The preparation of single cell suspensions is crucial for SC-ICP-MS analysis. In addition, the integrity of the cellular structure needs to be maintained after cell fixation. ${ }^{32}$ It can be seen from Fig. 1 that the HepG2 cells are monodisperse and the integrity is preserved after fixation. In order to reduce the interference and improve the $\mathrm{S} / \mathrm{B}$ ratios, the cells are re-suspended in ultrapure water. In SC-ICP-MS, the number of cells in suspension must be carefully controlled, based on the calculation of transport efficiency, to ensure that only one cell enters the plasma during each dwell time.

Transport efficiency of the high-efficiency sample introduction system. In this work, a new high-efficiency sample introduction system is designed and produced. Fig. 2 shows the schematic diagram of the system, which mainly consists of a microconcentric nebulizer and a single pass spray chamber. The microconcentric nebulizer produce finer droplets that can transport more efficiently through the single pass spray chamber. Two make-up gas flows are introduced tangentially through the chamber walls, thus preventing single cells from sticking to the walls and improving the transport efficiency of the cells. The new sample introduction system, which is designed by us and built by Viktor Beijing Technology, is easily installed on the ICP-MS. Fig. 3 shows internal and external views of the system. The nebulizer and spray chamber in the system are easily aligned with the injector and are prevented from accidental damage.

According to previous reports, ${ }^{31}$ the single cell events detected by ICP-MS in each dwell time can be calculated by the Equation (1):

$$
\mathrm{n}=\varepsilon \cdot \mathrm{Qs} \cdot \mathrm{C} \cdot \mathrm{t}_{\mathrm{dwell}}
$$

where $\mathrm{n}$ is the number of detected cells in a dwell time (s); $\varepsilon$ is the transport efficiency (TE) of single cells; Qs is uptake rate of single cell suspensions $\left(\mathrm{mL} \mathrm{s}^{-1}\right)$; $\mathrm{C}$ is the number concentration of single

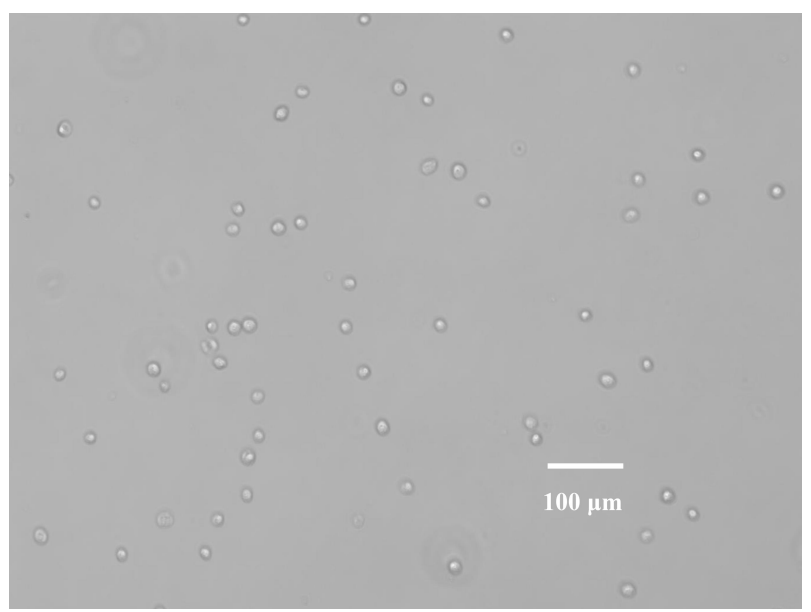

Fig. 1 The image of HepG2 cells in deionized water after fixation with $70 \%$ (v/v) ethanol. The scale bar: $100 \mu \mathrm{m}$.

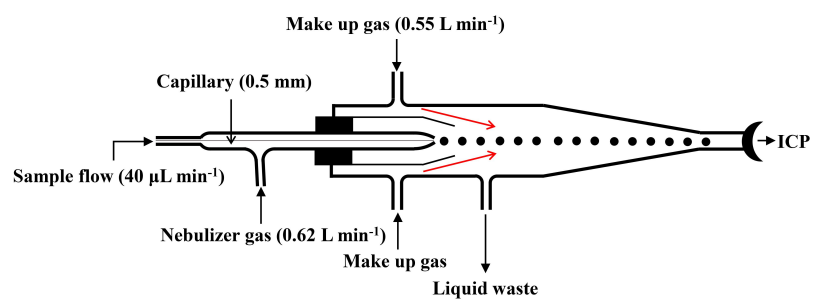

Fig. 2 The schematic diagram of the high-efficiency sample introduction system. Total make-up gas flow is $0.55 \mathrm{~L} \mathrm{~min}^{-1}$.

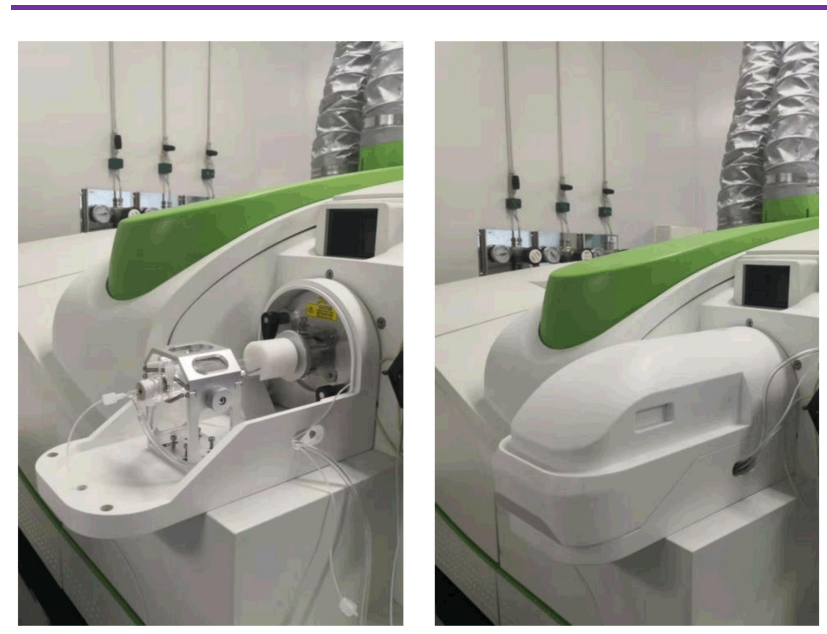

Fig. 3 The high-efficiency sample introduction system. Left: internal view; Right: external view.

cells $\left(\mathrm{mL}^{-1}\right)$; $\mathrm{t}_{\mathrm{dwell}}$ is the dwell time (s).

In SC-ICP-MS analysis, $\mathrm{n}$ should be less than 1. The key parameter, transport efficiency $(\varepsilon)$, which is dependent on the sample introduction system used, is determined by introduction of a known number of cells. In this work, a known number of single 


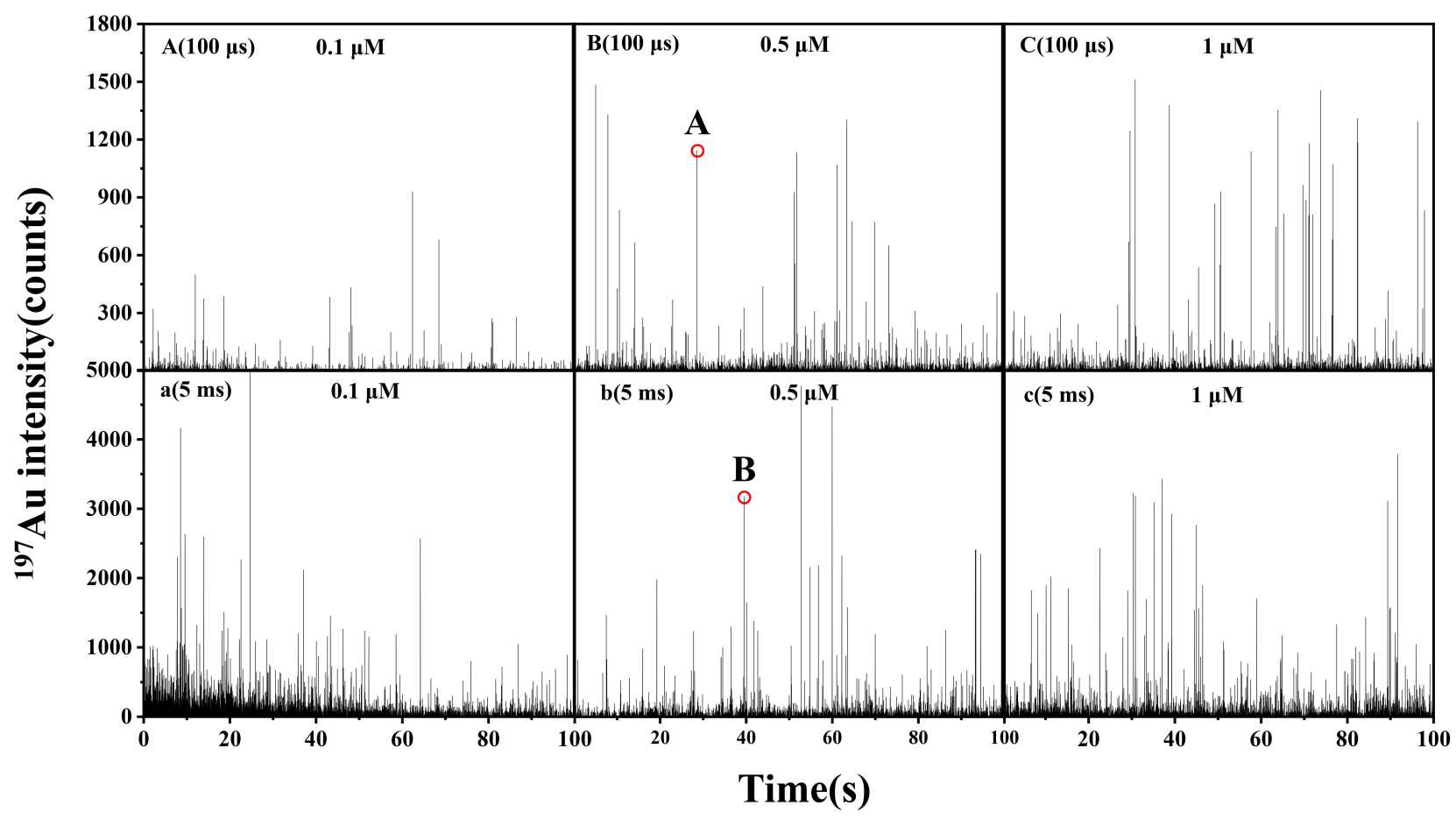

Fig. 4 The SC-ICP-MS spectra of ${ }^{197} \mathrm{Au}$ in HepG2 cells after incubation with AuNPs $(0.1,0.5$, and $1 \mu \mathrm{M})$ for $12 \mathrm{~h}$. The two spike signals (A and B) labeled by red circles are enlarged in Fig 5 .
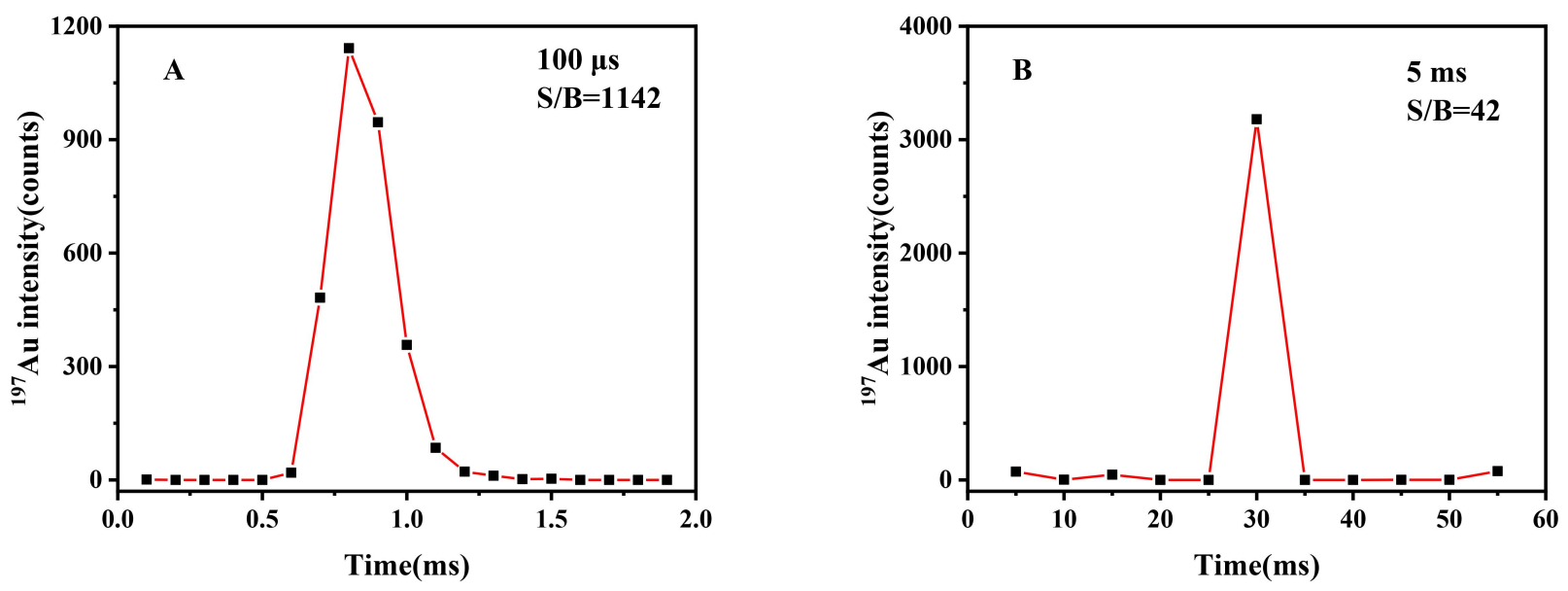

Fig. 5 The enlargements of two spike signals labelled by red circles in Fig 4. A: the S/B ratio of Au is 1142 when dwell time is $100 \mu$ s; B: the $\mathrm{S} / \mathrm{B}$ ratio of $\mathrm{Au}$ is 42 when dwell time is $5 \mathrm{~ms}$.

cells in suspension were counted with a hemocytometer, introduced into the ICP-MS, and analyzed in a time-resolved mode. The ratios of the single-cell events to the single cells introduced were calculated as the transport efficiency. Our results showed that the transport efficiency of the system for single cells was $\sim 12 \%$, which is better than many reports in the literature. ${ }^{17}$ Under these circumstances, the optimal number of cells in suspension was $\sim 10^{5} \mathrm{~mL}^{-1}$ for SC-ICP-MS.

Quantitative analysis of Au NPs in single cells. The quadrupole ICP-MS used in this work can continuously monitor a single isotope with zero settling time and a dwell time as low as $10 \mu \mathrm{s}$.
Fig. 4 shows the SC-ICP-MS spectra of ${ }^{197} \mathrm{Au}$ in the HepG2 cells at the dwell time of $100 \mu$ s and $5 \mathrm{~ms}$, respectively. The Au signals of $5 \mathrm{~ms}$ dwell time were higher than those of $100 \mu \mathrm{s}$ dwell time. However, the ${ }^{197} \mathrm{Au}$ signal-to-background ratio (S/B) at $100 \mu \mathrm{s}$ dwell time was much higher than at $5 \mathrm{~ms}$. For example, Fig. 5 is the enlargement of two spike signals labeled by red circles in Fig 4, showing that the $\mathrm{S} / \mathrm{B}$ ratio of $100 \mu$ s dwell time was 27 -fold higher than that of $5 \mathrm{~ms}$. Therefore, the $100 \mu \mathrm{s}$ dwell time was chosen for subsequent experiments. Our results showed that in comparison to a $5 \mathrm{~ms}$ dwell time, the dwell time of $100 \mu$ s can improve the S/B ratios in SC-ICP-MS, which agrees with the results in the literature. ${ }^{33}$ 


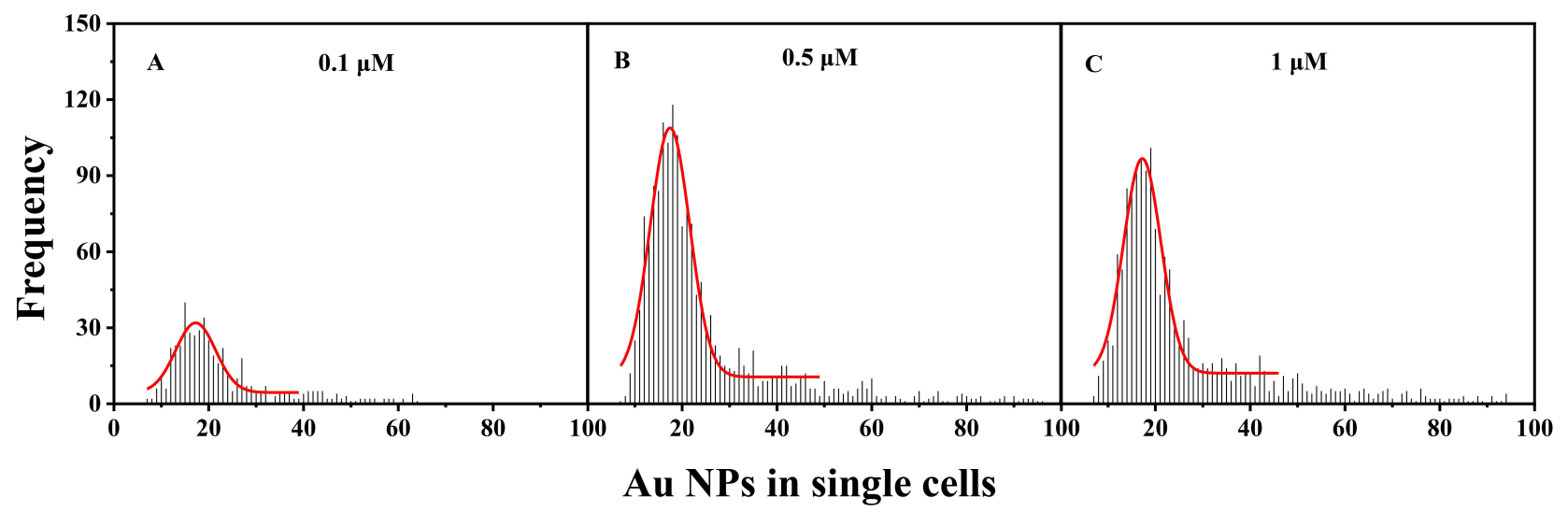

Fig. 6 Histograms of AuNPs in single HepG2 cells after incubation with Au NPs (40 nm) at $0.1 \mu \mathrm{M}(\mathrm{A}), 0.5 \mu \mathrm{M}(\mathrm{B}), 1.0 \mu \mathrm{M}(\mathrm{C})$ for $12 \mathrm{~h}$.

Table 2 Au Mass in the Cells Exposed to AuNPs

\begin{tabular}{lll}
\hline \multirow{2}{*}{$\begin{array}{l}\text { Exposure } \\
\text { concentrations of }\end{array}$} & \multicolumn{2}{c}{ Au mass per cell (fg) } \\
\cline { 2 - 3 } AuNPs $(\boldsymbol{\mu M})$ & SC-ICP-MS & $\begin{array}{l}\text { Solution analysis by } \\
\text { ICP-MS }\end{array}$ \\
\hline $\mathbf{0 . 1}(\mathbf{n}=\mathbf{4 9 1 )}$ & $23 \pm 8$ & 24.2 \\
$\mathbf{0 . 5}(\mathbf{n}=\mathbf{1 6 1 8})$ & $25 \pm 16$ & 26.9 \\
$\mathbf{1 . 0}(\mathbf{n}=\mathbf{1 5 0 4})$ & $26 \pm 17$ & 35.4 \\
\hline
\end{tabular}

$\mathrm{n}$ : the number of single cells determined.

Both the NPs and the trace element standard solution can be used as calibration for the quantification of NPs in single cells. In this work, AuNP standard materials were used for the quantitative analysis by SC-ICP-MS. The calibration method depends on the assumption that the intracellular AuNPs exhibit the same ionization behaviors to the AuNPs in suspension. In order to validate the SC-ICP-MS results, the average masses of the AuNPs in the cell populations were also determined by acid digestion and solution analysis with ICP-MS. No detectable Au signals were found in the control cells, thus the Au signals in the single cells come from the intracellular AuNPs. Fig. 6 shows the histogram of distribution of the AuNPs in single cells after exposure of 0.1, 0.5, and $1.0 \mu \mathrm{M}$ for $12 \mathrm{~h}$. The uptake of the AuNPs by single HepG2 cells follow the Gaussian distribution. According to the specification from the manufacturer, one AuNP is $43.7 \mathrm{~nm}$ in diameter and contains $\sim 0.843 \mathrm{fg} \mathrm{Au}$ on average. When the dwell time is set at $100 \mu \mathrm{s}$, one AuNP produces a peak area of $3.13 \pm 0.11$ count $\cdot \mathrm{ms}$ in SC-ICP-MS. The quantitative results (Table 2) show that the cellular uptake of AuNPs increases with an increase in AuNP exposure dose. The SC-ICP-MS data using NP calibration are in good agreement with those using solution ICP-MS analysis, validating the developed SC-ICP-MS method. The data obtained provide clear evidence that single cells behave differently after AuNP exposure.

\section{CONCLUSIONS}

In this work, a high-efficiency sample introduction system was used for SC-ICP-MS analysis which improves the transport efficiency of single cells up to $\sim 12 \%$. In comparison with a $5 \mathrm{~ms}$ dwell time, the $\mathrm{S} / \mathrm{B}$ ratios can be greatly improved by collecting data at a dwell time of $100 \mu$ s. In SC-ICP-MS, calibration by standard NPs can provide accurate results. The SC-ICP-MS has the capability to evaluate cell-to-cell variation and is expected to be widely applied in the future in biomedical research.

\section{AUTHOR INFORMATION}

\section{Corresponding Author}

*M. Wang

Email address: wangmeng@ihep.ac.cn

\section{*M. L. Chen}

Email address: chenml@mail.neu.edu.cn

Notes

The authors declare no competing financial interest.

\section{ACKNOWLEDGMENTS}

The authors gratefully thank the Natural Science Foundation of China (21974116) and the National Basic Research Program of China (2016YFA0201600) for financial support of this work. 


\section{REFERENCES}

1. X. P. Han, Z. M. Zhou, L. J. Fei, H. Y. Sun, R. Y. Wang, Y. Chen, H. D. Chen, J. J. Wang, H. N. Tang, W. H. Ge, Y. C. Zhou, F. Ye, M. M. Jiang, J. Q. Wu, Y. Y. Xiao, X. N. Jia, T. Y. Zhang, X. J. Ma, Q. Zhang, X. L. Bai, S. J. Lai, C. X. Yu, L. J. Zhu, R. Lin, Y. C. Gao, M. Wang, Y. Q. Wu, J. M. Zhang, R. Y. Zhan, S. Y. Zhu, H. L. Hu, C. C. Wang, M. Chen, H. Huang, T. B. Liang, J. H. Chen, W. L. Wang, D. Zhang, and G. J. Guo, Nature, 2020, 581, 303-309. https://doi.org/10.1038/s41586-020-2157-4

2. H. W. Jackson, J. R. Fischer, V. R. T. Zanotelli, H. R. Ali, R. Mechera, S. D. Soysal, H. Moch, S. Muenst, Z. Varga, W. P. Weber, and B. Bodenmiller, Nature, 2020, 578, 615-620. https://doi.org/10.1038/s41586-019-1876-x

3. J. Li, H. Mao, N. Kawazoe, and G. Chen, Biomater. Sci., 2017, 5, 173-189. https://doi.org/10.1039/C6BM00714G

4. X. Li, B. Wang, S. Zhou, W. Chen, H. Q. Chen, S. S. Liang, L. N. Zheng, H. Y. Yu, R. X. Chu, M. Wang, Z. F. Chai, and W. Y. Feng, J. Nanobiotechnol., 2020, 18, 1-16. https://doi.org/10.1186/s12951-020-00599-1

5. A. Ivask, A. J. Mitchell, A. Malysheva, N. H. Voelcker, and E. Lombi, Wiley Interdiscip. Rev.-Nanomed. Nanobiotechnol., 2018, 10, 1-22. https://doi.org/10.1002/wnan.1486

6. Z. Z. Yu, Q. H. Wu, S. L. Zhang, J. Y. Miao, B. X. Zhao, and L. Su, RSC Adv., 2016, 6, 10159-10161. https://doi.org/10.1039/C5RA21322C

7. J. C. Li, J. J. Li, J. Zhang, X. L. Wang, N. Kawazoe, and G. P. Chen, Nanoscale, 2016, 8, 7992-8007. https://doi.org/10.1039/C5NR08808A

8. C. Grabinski, N. Schaeublin, A. Wijaya, H. D'Couto, S. H. Baxamusa, K. Hamad-Schifferli, and S. M. Hussain, ACS Nano, 2011, 5, 2870-2879. https://doi.org/10.1021/nn103476x

9. S. Kim and D. Y. Ryu, J. Appl. Toxicol., 2013, 33, 78-89. https://doi.org/10.1002/jat.2792

10. I. L. Hsiao, F. S. Bierkandt, P. Reichardt, A. Luch, Y. J. Huang, N. Jakubowski, J. Tentschert, and A. Haase, J. Nanobiotechnol., 2016, 14, 1-13. https://doi.org/10.1186/s12951-016-0203-Z

11. D. J. Wang and S. Bodovitz, Trends. Biotechnol., 2010, 28, 281-290. https://doi.org/10.1016/j.tibtech.2010.03.002

12. M. Wang, L. N. Zheng, B. Wang, H. Q. Chen, Y. L. Zhao, Z. F. Chai, H. J. Reid, B. L. Sharp, and W. Y. Feng, Anal. Chem., 2014, 86, 10252-10256. https://doi.org/10.1021/ac502438n

13. Y. K. Li, T. Yang, M. L. Chen, and J. H. Wang, Talanta, 2018, 180, 18-24. https://doi.org/10.1016/j.talanta.2017.12.020

14. M. T. Liu, X. F. Mao, J. X. Liu, L. Ding, X. Na, G. Y. Chen, and Y. Z. Qian, At. Spectrosc., 2019, 40, 83-90. https://doi.org/10.46770/AS.2019.03.002

15. O. Topdagi, O. Toker, S. Bakirdere, E. Oz, E. O. Bursalioglu, M. Abuqbeitah, M. Demir, and O. Icelli, At. Spectrosc., 2020, 41, 29-35. https://doi.org/10.46770/AS.2020.01.004
16. H. Wang, M. He, B. B. Chen, and B. Hu, J. Anal. At. Spectrom., 2017, 32, 1650-1659. https://doi.org/10.1039/C6JA00414H

17. X. Yu, M. He, B. Chen, and B Hu, Anal. Chim. Acta., 2020, 1137, 191-207. https://doi.org/10.1016/j.aca.2020.07.041

18. F. M. Li, D. W. Armstrong, and R. S. Houk, Anal. Chem., 2005, 77, 1407-1413. https://doi.org/10.1021/ac0491881

19. K.-S. Ho and W.-T. Chan, J. Anal. At. Spectrom., 2010, 25, 1114-1122. https://doi.org/10.1039/C002272A

20. L. N. Zheng, M. Wang, B. Wang, H. Q. Chen, H. Ouyang, Y. L. Zhao, Z. F. Chai, and W. Y. Feng, Talanta, 2013, 116, 782-787. https://doi.org/10.1016/j.talanta.2013.07.075

21. L. N. Zheng, M. Wang, L. C. Zhao, B. Y. Sun, B. Wang, H. Q. Chen, Y. L. Zhao, Z. F. Chai, and W. Y. Feng, Anal. Bioanal. Chem., 2015, 407, 2383-2391. https://doi.org/10.1007/s00216-014-8422-3

22. H. Wang, B. Chen, M. He, and B. Hu, Anal. Chem., 2017, 89, 4931-4938. https://doi.org/10.1021/acs.analchem.7b00134

23. X. Wei, D. H. Zheng, Y. Cai, R. Jiang, M. L. Chen, T. Yang, Z. R. Xu, Y. L. Yu and J. H. Wang, Anal. Chem., 2018, 90 , 14543-14550. https://doi.org/10.1021/acs.analchem.8b04471

24. X. Wei, X. Zhang, R. Guo, M. L. Chen, T. Yang, Z. R. Xu, and J. H. Wang, Anal. Chem., 2019, 91, 15826-15832. https://doi.org/10.1021/acs.analchem.9b04122

25. X. Zhang, X. Wei, X. Men, Z. Jiang, W.-Q. Ye, M.-L. Chen, T. Yang, Z.-R. Xu, and J.-H. Wang, Anal. Chem., 2020, 92, 6604-6612. https://doi.org/10.1021/acs.analchem.0c00376

26. J. W. Olesik and P. J. Gray, J. Anal. At. Spectrom., 2012, 27, 1143-1155. https://doi.org/10.1039/C2JA30073G

27. Z. Liu, A. Xue, H. Chen, and S. Li, Appl. Microbiol. Biotechnol., 2019, 103, 1475-1483. https://doi.org/10.1007/s00253-018-09587-w

28. H. Wang, B. Wang, M. Wang, L. Zheng, H. Chen, Z. Chai, Y. Zhao, and W. Feng, Analyst, 2015, 140, 523-531. https://doi.org/10.1039/C4AN01610F

29. H. Wang, M. Wang, B. Wang, L. Zheng, H. Chen, Z. Chai, and W. Feng, Anal. Bioanal. Chem., 2017, 409, 1415-1423. https://doi.org/10.1007/s00216-016-0075-y

30. X. Wei, L. L. Hu, M. L. Chen, T. Yang, and J. H. Wang, Anal. Chem., 2016, 88, 12437-12444. https://doi.org/10.1021/acs.analchem.6b03810

31. H. E. Pace, N. J. Rogers, C. Jarolimek, V. A. Coleman, C. P. Higgins, and J. F. Ranville, Anal. Chem., 2011, 83, 9361-9369. https://doi.org/10.1021/ac201952t

32. M. R. Filipovic, A. C. W. Koh, S. Arbault, V. Niketic, A. Debus, U. Schleicher, C. Bogdan, M. Guille, F. Lemaitre, C. Amatore, and I. Ivanovic-Burmazovic, Angew. Chem.-Int. Edit., 2010, 49, 4228-4232. https://doi.org/10.1002/anie.200905936

33. S. I. Miyashita, A. S. Groombridge, S. I. Fujii, A. Minoda, A. Takatsu, A. Hioki, K. Chiba, and K. Inagaki, J. Anal. At. Spectrom., 2014, 29, 1598-1606. https://doi.org/10.1039/C4JA00040D 